\title{
Competencies of the present-day Graphic Designer: A document analysis of online job ads in Ghana
}

\begin{abstract}
This study sought to provide an overview of the competencies required by employers in advertising for graphic design position in relation to interactive design in Ghana. This was done in the context of the dynamism of graphic design profession with current technological advances. Both thematic and content analysis were used to analyse online job advertisements collected within eight months to determine the patterns and frequencies of occurrence of specific requirements for the job position relating to graphic design. This was to better understand employers' expectations from the graphic designer in terms of designing for interactivity and the implications for graphic design pedagogy. Findings from the study revealed that, traditional graphic designers in Ghana will now have to acquire skills in interactive design and competencies associated with them. These include among others, responsive design, problem-solving, coding skill, software skills, creativity, CMS tools, project management and personal characteristics. Beyond these, request for skills in coding, knowledge in responsive design, knowledge in content management system tools, software skills and teamwork are the most frequently expected skills from the present day graphic designer. We end the paper by suggesting how our study could trigger graphic design pedagogy development.
\end{abstract}

\section{KEY WORDS}

Graphic design, job ads, design competencies, design education, interactive design

\author{
Nicholas Opoku ${ }^{1}$ (1) \\ Edward Appiah ${ }^{2}$ \\ Patrique deGraft-Yankson ${ }^{1}$ \\ ${ }^{1}$ University of Education, \\ Department of Graphic Design, \\ Winneba, Ghana \\ ${ }^{2}$ Kwame Nkrumah University of \\ Science and Technology, \\ Department of Communication \\ Design, Kumasi, Ghana
}

Corresponding author:

Nicholas Opoku

e-mail:

opoku.nickky@gmail.com

First recieved: 22.03.2020.

Accepted: 26.05.2020.

\section{Introduction}

With advent of technologies, couple with dynamism in the graphic design industry, graphic design graduates and students face diverse demands by organizations in applying for job position. The requirements placed on graphic designers also form an essential discourse for design educators in ensuring the employability of their students when they graduate. As the scope and content for graphic designers evolve in the industry (Davis, 2005; Ashigbey, 2016; Dziobczenski \& Person, 2017), the competencies required to practice as a designer is also changing.

\section{Graphic Design Practices in Ghana}

The practice of graphic design is not a novel field. From the Guttenberg era, which was characterized with the transfer of text matter onto paper through to the production of graffiti's, which is not limited to the beautification of our landscape scenes, graphic design has evolved into a new phenomenon taking an interesting tangent.

In the case of Ghana, the practice of graphic design is known to have been characterized with the use of handy tools such as pencils, calligraphy pens, artists' brushes, etc. to communicate visually. In this phase of practice, the predominant substrates were paper, fabric and wall surfaces. The advent of the computer and subsequent 
features of design software, such as CorelDraw, Page Maker, Photoshop, Illustrator, and InDesign introduced precision and accuracy in the final output of graphic designer's work. Though these computer generated graphic design applications did not totally annihilate the use of the traditional devices in the industry by those who saw themselves as avant-gardes, it is important to note that they limited production time. Reckoning that these software ensured precision, several graphic design firms have been established in almost every nook and cranny of the country typically, promoting a vibrant printing industry in Accra and Kumasi, the two major cities.

Technological advancement in graphic design practice has seen graphic design content moving to virtual, powered by sophisticated computer programming language. This phenomenon appears to be affecting the current stage of the graphic design community in Ghana. Designing for interactivity is gradually gaining popularity as most businesses in Ghana especially those in the financial sector have resorted to the use of mobile applications and websites with interesting graphic design content to communicate with their clients making contact hours at the banks relatively less. With globalization effects on graphic design industry and ubiquitous growth of the Internet, one can post design problem on the Internet and get someone elsewhere to design for them. This puts the traditional Ghanaian graphic designer in a fierce competing battle with other graphic designers globally for the same job. Ghana is considered one of the emerging vital players in digital economy and over 9 million jobs will require coding skills by 2030 as reported in International Finance Corporation (IFC) 2019 report (IFC, 2019). The use of mobile devices by Ghanaians is gradually making the practice of graphic design transit from the conventional print media to one, which is technologically driven. This brings a new dimension to how graphic design as an industry is evolving as a new designer titles such as UI designer, UX designer, web designer, etc. are being offered to the graphic designer in job listing. In this paper we provide an overview of the competencies required by employers in advertising graphic design positions in relation to interactive design through job advertisements. We asked the question, "what are the expected competencies employers referenced in advertising for graphic design position in relation to interactive design?"

\section{Literature Review}

\section{Graphic Design Practice in the Digital Era}

Graphic design, which traditionally is about communicating visually and presenting information to the targeted audience, has witnessed many changes in the digital media era. Earlier, the domain of graphic design practice was limited to print media. However, following advancement in industry, growth of interactive tech- nologies, and increase in mobile device usage for visual communication, transforming ideas into visual solutions and communicating ideas via visual components such as colour, pictures and typography in digital media has also been regarded to be the duties of graphic designers (Bestley \& Noble, 2016; Dziobczenski \& Person, 2017). Today, graphic designers are found in various positions such as UI designer, UX designer, web designer, among others within industry, forcing designers to adapt and expand their competencies in relation to a scope of new activities and responsibilities. As indicated by Ashigbey (2016) 'design is currently migrating to digital platform, we are preparing to take our newspapers to multimedia platforms and there is the need for designers to acquaint themselves'. This assertion therefore calls for new skills and competencies to keep the designer in the job market. From mobile application user interface design to website design, the job prospects for graphic designer in Ghana are now taking a dynamic trend.

\section{The Job Market Demands}

A good place to start when mapping the competencies designers should possess is to consider the kind of qualifications the industry looks for when hiring a designer. Studies have shown that designers with contextual understanding, proficient design skills, planning and integration capabilities, design knowledge, programming skills like PHP, HTML, CSS, knowledge in the use of prototyping tools such as Axure, Adobe $X D$, Sketch, etc. are more likely to be hired (Sørum \& Pettersen, 2016; Dziobczenski \& Person, 2017; Dziobczenski, Person \& Meriläinen, 2018; Dziobczenski et al., 2018). The most successful designer will be those who can work with intangible materials - code, voice, and words (Maeda, 2017). Figure 1 indicates example of recent job listings that display how the role of graphic designer has expanded to include interactive design.

\section{Methodology}

In this study, we pursued document (thematic and content) analysis of job ads in which we combined thematic and content analysis as way of analysing both electronic and printed texts created without the researchers' intervention (Bowen, 2009). Ritchie et al. (2013) claim that job offers provide natural occurring data written to the interest of both applicant and employers.

\section{Job Advertisement Analysis}

We gathered job advertisements for graphic designers in relation to interactive design from online recruitment platforms over a period of six months (September, 2017 May, 2018). Job advertisements have been used to study trends and requirements placed on other professionals (Wade \& Parent, 2002; Choi \& Rasmussen, 2009; Smith 


\begin{tabular}{|c|c|c|}
\hline $\begin{array}{l}\text { Job Portal } \\
\text { Home }\end{array}$ & \multicolumn{2}{|c|}{ Vacancy: Graphic \& Web Designer in Accra } \\
\hline Jobberman Ghana & Company & Not disclosed \\
\hline \multirow{2}{*}{$\begin{array}{l}\text { Search through hundreds } \\
\text { of jobs posted daily }\end{array}$} & Location & Dzorwulu \\
\hline & Job Category & Media \\
\hline \multirow{2}{*}{$\begin{array}{c}\text { Join Jobberman.com.gh now } \\
\text { Wbberman } \\
\end{array}$} & Job Type & Permanent/Full Time \\
\hline & Working Experience & 1 - 3 Years \\
\hline \multirow{6}{*}{ Advertisement } & Education Level & High School/Senior Secondary School \\
\hline & Application Deadline & $18-11-2017$ \\
\hline & Industry & IT Jobs \\
\hline & Qualifications & Creative with up-to-date knowledge in IT \\
\hline & Salary Range & $\mathrm{GH} \phi 700.00-\mathrm{GH} \phi 1,000.00$ \\
\hline & Description & $\begin{array}{l}\text { Job Summary We are looking for a creative Graphic designer with up-to-date } \\
\text { knowledge to interpret our clients' needs and to design solutions with high } \\
\text { visual impact. You will work on a variety of products, including websites, } \\
\text { product packaging, websites, exhibitions, corporate identity etc. and you will } \\
\text { cooperate with our designers and marketing team. Responsibilities Thinking } \\
\text { creatively and developing new design concepts, graphics and layouts } \\
\text { Schedule project implementation and define budget constraints Work with a } \\
\text { wide range of media and use graphic design software Prepare rough drafts } \\
\text { and present your ideas Take the design "brief" to record requirements and } \\
\text { clients' needs Amend final designs to client's comments and gain full } \\
\text { approval Work as part of a team with copywriters, designers, stylists, } \\
\text { executives etc. Requirement: Proven graphic designing and web } \\
\text { designing/development experience Possession of creative flair, versatility, } \\
\text { conceptual/visual ability and originality Ability to interact, communicate and } \\
\text { present ideas Highly proficient in all design aspects Demonstrable graphic } \\
\text { design and Web design/development skills with a strong portfolio Up to date } \\
\text { with industry leading software and technologies (In Design, Illustrator, } \\
\text { Photoshop, WordPress, Dreamweaver etc.) "*Applicants that have } \\
\text { knowledge in designing websites using standard HTML/CSS practices will } \\
\text { be at an advantage. Same applies to applicants that have knowledge in }\end{array}$ \\
\hline
\end{tabular}

» Figure 1: Sample of job ads

\& Ali, 2014; Grigoriadis, 2014). In design, job ads have been used to study the competence on new design graduates, skills companies require from industry designers, and skills set of graphic designers (Yang, You \& Chen, 2005; Ramirez, 2012; Dziobczenski \& Person, 2017; Dziobczenski, Person \& Meriläinen, 2018). Publicly available job listings is claimed to be a genuinely representative list of what is available with respect to the knowledge and skills in demand (Molinero \& Xie, 2007; Kennan et al., 2009). The job search portals include Job House (jobhouse.com. gh), VimJobs (vimjobs.com), GhanaWeb (ghanaweb.com/ GhanaHomePage/jobs), Ghana Current Jobs (ghanacurrentjobs.com), Joblist Ghana (joblistghana.com), and Jobberman (jobberman.com.gh). The search covered job offers with the term 'graphic designer' in the job title. It was discovered that graphic designers working for interactivity positions are advertised under a diverse titles (e.g. front-end designer, UX designer, UI designer, web designer). The second search covered ads with the term 'designer' in the job title, 'interactive designer, front-end designer, UX designer, UI designer, web designer' in the job description. Following this course of action, we managed to gather an initial set of 103 job advertisements.

\section{Data Refinement}

During data gathering, it became apparent that recruiters frequently publish the same job advertisements on multiple recruitment platforms. In printing the advertisements, jobs published by the same organization under the same job title on different recruitment platforms were captured as one. Finally, only job ads where the job title contained graphic designer, digital designer, web designer, UX designer, and UI designer were included in refining the data. In doing so, certain advertisements that did not require the competencies for the expertise of interactive design were excluded. As a result of data refinement, the initial sample of 103 advertisements was reduced to 57 unique job advertisements for the analysis.

\section{Analysis}

Similar to other studies (Yang, You \& Chen, 2005; Ramirez, 2012; Sørum \& Pettersen, 2016; Dziobczenski \& Person, 2017), we approached the knowledge and skill sets of designers as a multifaceted. Thematic analysis was utilized to ascertain an initial set of patterns to recount what recruiters required from designers who engaged in interactive design in the job offers. As indicated by Lapadat (2010), thematic analysis is appropriate to work with a lot of written information without losing context. The initial coding plan was made by examining the job offers while inductively mapping what was required from designers, in connection to interactive design practice through manual coding. A set of patterns recounting what recruiters anticipated from designers in the job offers was ascertained through this technique and later re-examined, updated, and refined. In evaluating the quality and relevance of the outcomes, we expanded the analysis by performing a content analysis 
of the data set. Specifically, we set out to evaluate the recurrence and noteworthiness of the themes that have emerged from the knowledge and skill set requirements in the job advertisements. This was done by mapping out the number of job offers captured in the advert (presence or absence). Less recurrence codes were combined to produce more holistic and descriptive patterns.

For the final coding plan, Richard Voorhees' conceptual learning model (a competence-based view of education) as captured in Figure 2, was utilized as a lens to sought the connection between requirements in the job advertisement and structured the results of the analysis in terms of competence areas, knowledge and skills, and personal traits.

\section{Results}

The analysis revealed patterns in what employers anticipated from designers in the job offers (figure 3). Altogether, the final coding plan comprises five main themes and 18 sub-themes (CA.1, CA.2, KS.1, etc.). The job offers in the data set comprise a broad number of competence, knowledge and skills, and personal traits. Additionally, 48 (indicating $84.2 \%$ ) job offers made mention of two or more "knowledge and skills" demonstrating that employers seek designers who can execute projects in multiple areas. Details of these qualities are presented in the appendix. Figure 3 gives an overview of different types of knowledge and skills required from a graphic designer as captured in the analysis.

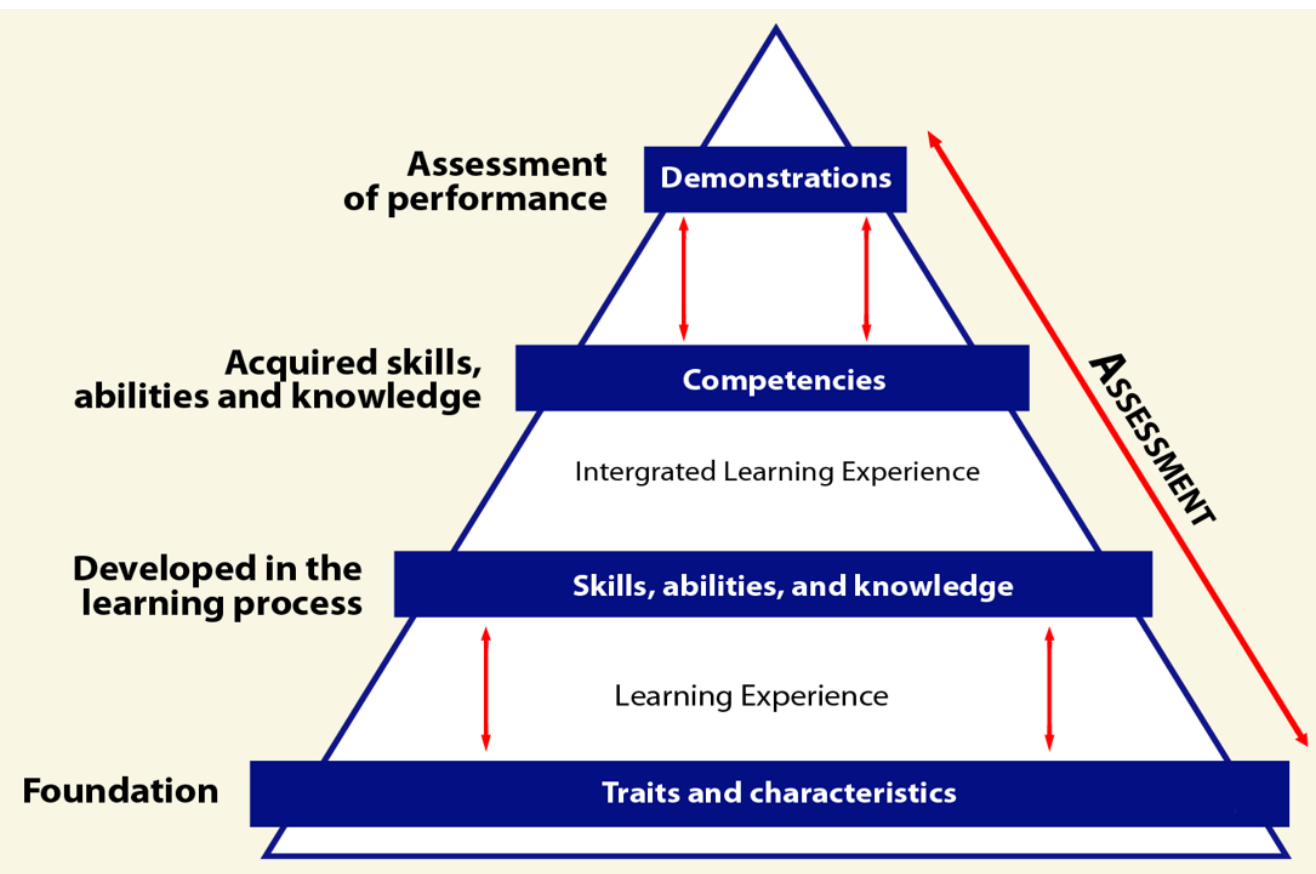

» Figure 2: Conceptual learning model pyramid: Voorhees (2001)

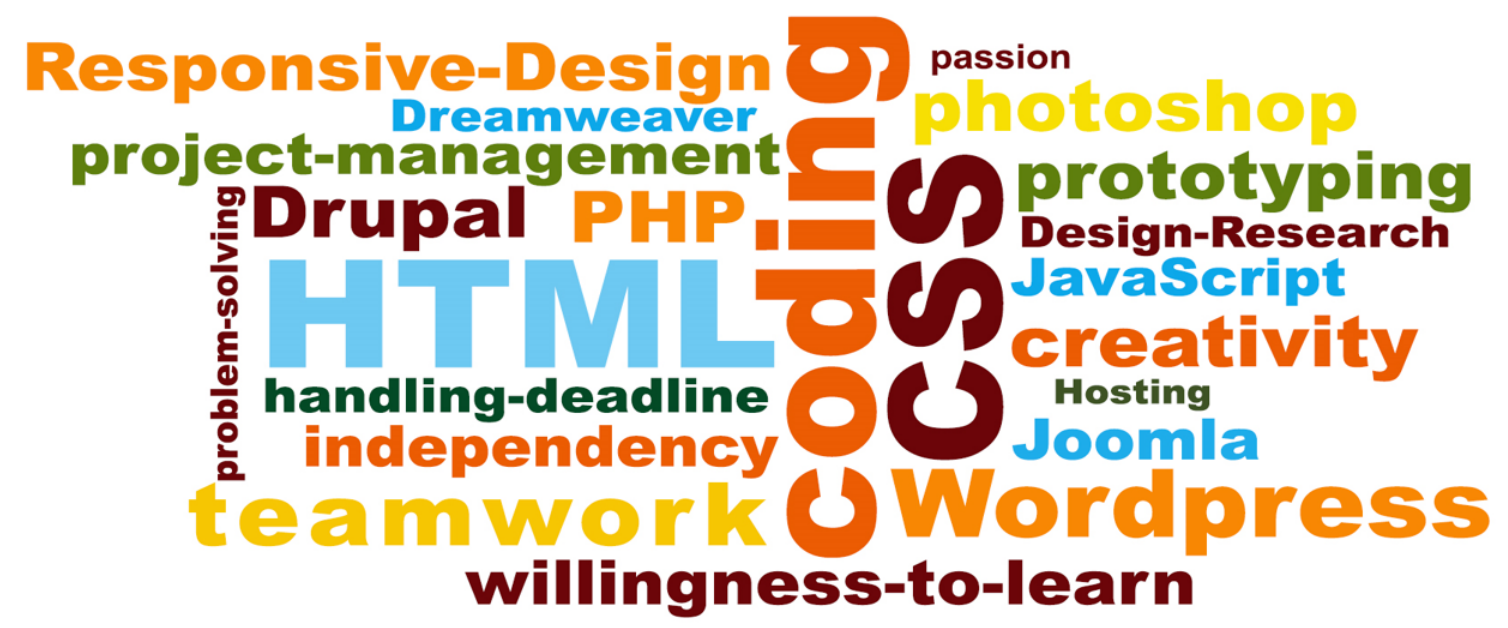

» Figure 3: Examples of knowledge and skills required from a graphic designer 


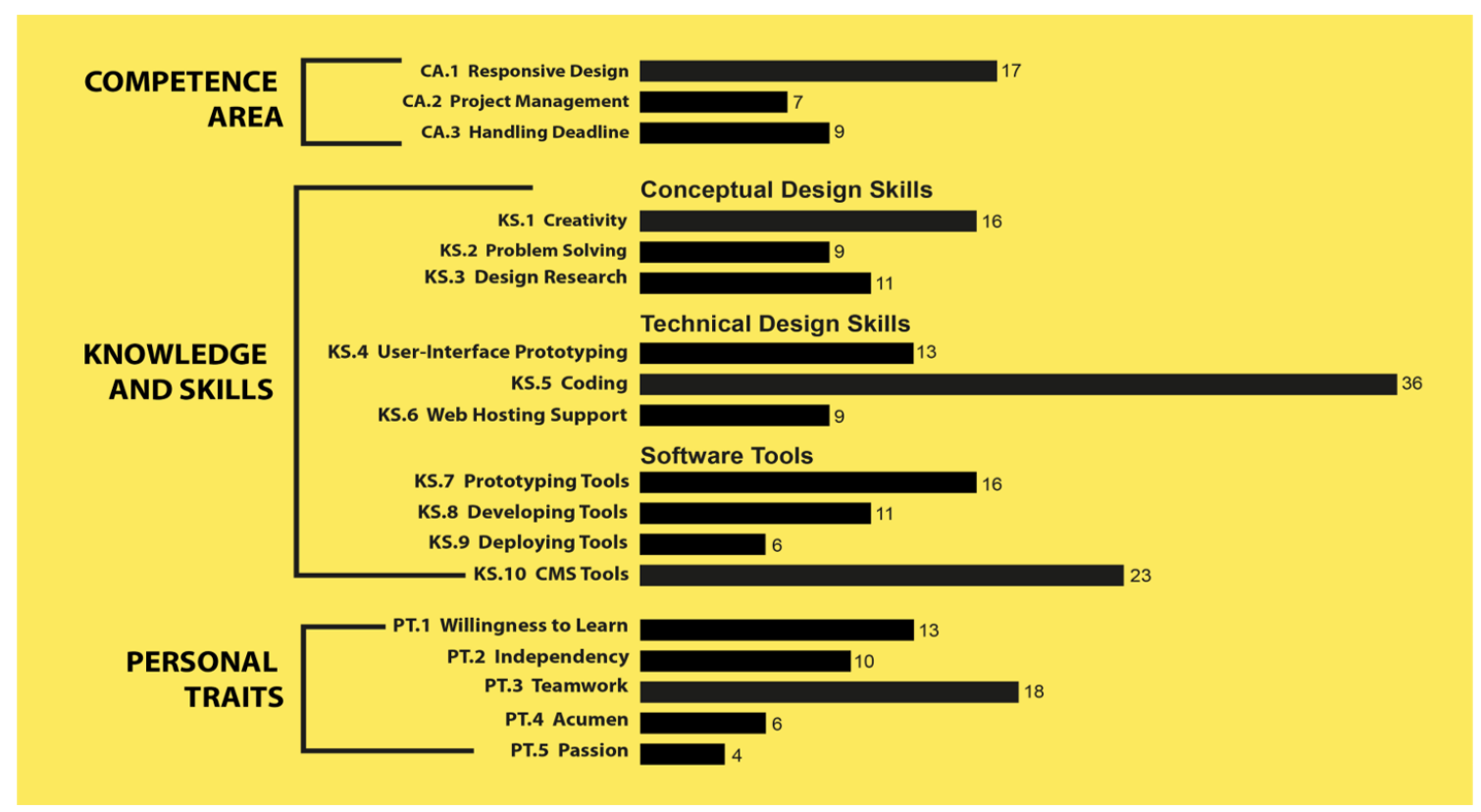

» Figure 4: Distribution of each subtheme in terms of frequency

The Competence Areas address what graphic designers should deliver through their work. Our analysis produced three kinds of these requests in the job ads: responsive design, project management and handling deadlines. Responsive design references the ability to design interactive content that focuses on a user's environment and behaviour based on the orientation and size of their interactive media screen as well as the platform. Project management includes reference to the ability of the designer to apply his knowledge, skills, tools, and techniques to manage multiple projects to meet the project requirements. Handling deadline comprises how designers should complete tasks within the time by which interactive design projects must be completed or submitted.

With regard to Knowledge and Skills, the study identified 10 subthemes across the job ads. Similar to Dziobczenski \& Person (2017), we classified the subthemes across three main themes: conceptual design skills, technical design skills and software tools as indicated in Figure 4.

The conceptual design skills theme describes how designers should have the capacity to support hands-on design work. Specifically, the related subthemes cover how interactive designers should have skills in creativity, problem-solving and design research. The technical design skills theme mentions the abilities and knowledge needed to perform design duties in day-to-day practice. Specifically, the associated subthemes cover knowledge and skills in user-interface prototyping, coding and web hosting supports. The use of software tools is fundamental in interactive design. In relation to design software tools used by designers, prototyping software, developing software, deploying software and content management system software were mentioned in the job advertisements.
Going beyond the main competencies graphic designers needed to design for interactivity, the requirements in the job ads also include statements that qualified applicants should display certain personality traits that support learning and professional practice. The study identified five reoccurring statements in the job ads that suitable applicants should hold "Acumen, Teamwork, Passion, Independence and Willingness to learn trends in the industry.

\section{Discussion}

This study through document analysis of job ads, sought to highlight the expectations of Ghanaian organizations regarding the kind of skills and competencies that graphic designers should possess in relation to designing for interactivity. Compared to some years back, many graphic designers today are marking themselves as UI designer, UX designer, web designer, interactive designers, resulting in a frequently used work position with a variety of duties performed.

The analysis suggests that designers who designed for interactivity are expected to possess a diverse skill set ranging from conceptual design skills to technical and software skills and personal traits. The most frequently cited competence area is found in responsive design. This illustrate the pressure that design companies in Ghana face from the variety of technological devices being used to access information and communication. The analysis also found that current awareness and suitable technical and software skills in the interactive design environment, abilities in creation and management of interactive content, and collaboration were the most requisite qualifications for interactive design 
position with high accentuation on coding abilities. Moreover, software tools such as Adobe Dreamweaver, Axure RP, Adobe Photoshop, InVision and FileZilla were sought frequently in the job advertisement.

These findings confirm the claims in previous studies about the high value employers place on these skills in other countries (Yang, You \& Chen, 2005; Ramirez, 2012; Dziobczenski \& Person, 2017) and are also in accordance with Grigoriadis (2014) study on job advertisements as indicators of the skills and competencies employers required from supply chain graduates. There is also a massive trend towards content management system (CMS) that helps clients to create, manage, and modify content on a website without the need for specialized technical knowledge and skills. In this regard, having knowledge in Wordpress, Joomla, Drupal, PHP, CSS, and HTML are fundamental for interactive designers to ensure interactive design projects adhere to standards and best practices for clients to be able to manage their own interactive content.

The findings also prove that the demand for project management skills, teamwork, problem-solving, and design research are emerging for interactive design practice. Ramirez (2012) announced that a successful case of internal collaboration and research help in completing industrial design projects. The demand for design research and leading industry software qualifications is an indication that there are new tools for designers in creating interactive content, and that software keeps changing within a slip of time due to technological advancement in interactive media for communication. To ensure the interactive designers consistently possess the evolving knowledge and skills for practice, they must have an accurate understanding of the processes within the interactive design environment. To do so, designers must possess the necessary core knowledge and skills of designing for interactivity as well as new technological knowledge and personal traits.

\section{Conclusion}

This study has explored the skills and competencies employers in the Ghanaian design industry are expecting from new graphic design graduates in terms of designing. Several key findings from this study make an essential contribution to understanding skills required by employers of graphic design graduates in the Ghanaian context. The most frequently require skills associated with coding consisting of knowledge and skills in HTML, CSS, JavaScript and PHP. This cluster of skills, which appeared in 63\% of the job advertisements, raises questions about the nature of the graphic designer work in today's technological era. The knowledge and skills in coding indicate that graduates with Computer Science and Software Engineering degrees might be better suited than Graphic Design graduates. On the other hand, it is easy to understand that design employers might be looking for graphic design graduates but with more emphasis on coding skills.

Graphic design is a rapidly changing profession due to technological advancement and while researches conducted some time back are useful and informative, it is imperative to continuously gather data about graphic design education and employment. While our study focuses on one aspect, job advertisements, there are other data for analysis such as interviewing employers and design educators, which could contribute to providing a bigger picture. To make it easier to understand graphic design professional careers as a whole we need more studies on the knowledge and skills required to practice graphic design in today's technological era where interactive media is been used for visual communication.

This study is not without limitations. We only analysed job advertisements from online recruitment platforms. Further studies could include an analysis of the graphic design programme offered by educational institutions. Also, future studies could involve practitioners, educators and organizations offering such position, their individual needs and expectations in relation to the tasks graphic designers are expected to perform and design pedagogy to teach it.

\section{References}

Ashigbey, K. (2016) How Graphic's Newspapers will become a Multimedia Platform. [Video] Available from: https://www.youtube.com/watch?v=Xjw2WFL90wA.

Bestley, R. \& Noble, I. (2016) Visual Research: An Introduction to Research Methods in Graphic Design. New York, Bloomsbury.

Bowen, G. (2009) Document Analysis as a Qualitative Research Method. Qualitative Research Journal. 9 (2), 27-40. Available from: doi: 10.3316/QRJ0902027

Choi, Y. \& Rasmussen, E. (2009) What Qualifications and Skills are Important for Digital Librarian Position in Academic Libraries? A Job Advertisement Analysis. Journal of Academic Librarianship. 35 (5), 457-567. Available from: doi: 10.1016/j.acalib.2009.06.003

Davis, M. (2005) Raising the Bar for Higher Education. In: Steven Heller (ed.). The Education of a Graphic Designer. New York, Allworth Press, pp. 13-18.

Dziobczenski, P., Person, O. \& Meriläinen, S. (2018) Designing career paths in graphic design: A document analysis of job advertisements for graphic design positions in finland. Design Journal. 21 (3), 349-370. Available from: doi: 10.1080/14606925.2018.1444874

Dziobczenski, P.R.. \& Person, O. (2017) Graphic Designer Wanted: A Document Analysis of the Described Skill Set of Grahphic Designers in Job Advertisments from the United Kingdom. International Journal of Design. 11 (2), 41-55. 
Dziobczenski, P. R. N., Person, O., Tonetto, L. M. \& Mandelli, R. R. (2018) Requests from Companies and Requirements for Design Education in Brazil: Where Do They Meet?. In: Storni, C., Leahy, K., McMahon, M., Lloyd, P. and Bohemia, E. (eds.). DRS 2018 Catalyst: Proceedings of DRS 2018, Design Research Society International Conference, 25-28 June 2018, Limerick, Ireland. London, Design Research Society. Available from: doi: 10.21606/drs.2018.535

Grigoriadis, N.S. (2014) Skills and Competencies Employers Require from Supply Chain Graduates: A job advertisements content analysis. Linnaeus University, Sweden.

IFC (2019) Digital Skills in Sub-Saharan Africa: Spotlight on Ghana. Available from: https://www.ifc. org/wps/wcm/connect/ed6362b3-aa34-42ac-ae9fc739904951b1/Digital+Skills_Final_WEB_5-7-19. pdf?MOD=AJPERES [Accessed: 15th May 2020].

Kennan, M. A., Willard, P., Cecez-Kecmanovic, D. \& Wilson, C. S. (2009) IS Knowledge and Skills Sought by Employers: A Content Analysis of Australian IS Early Career Online Job Advertisements. Australasian Journal of Information Systems. 15 (2), 169-190.

Lapadat, J.C. (2010) Thematic Analysis. In: Mills, A. J., Durepos, G. and Wiebe, E. (eds.) Encyclopedia of Case Study Research. London, Sage Publications, pp. 397399. Available from: doi: 10.4135/9781412957397. n342

Maeda, J. (2017) Design in Tech Report. Design in Tech. Available from: https://designintech.report/wp-content/uploads/2017/03/dit-2017-1-0-7-compressed. pdf [Accessed: 19th January 2018].

Molinero, M. C. \& Xie, A. (2007) What do UK Employers want from OR/MS?. The Journal of the Operational Research Society. 58 (12), 1543-1553. Available from: doi: $10.1057 /$ palgrave.jors.2602286
Ramirez, M. (2012) Employability Attributes for Industrial Design Graduates. In: Chova, L., Martinez, A. and Torres, I. (eds.) ICERI 2012 Proceedings: 5th International Conference of Education, Research and Innovation. 2012 pp. 2462-2471.

Ritchie, J., Lewis, J., Nicholls, C. \& Ormston, R. (2013) Qualitative Research Practice: A Guide for Social Science Students and Researchers. Thousand Oaks, Sage.

Smith, D. \& Ali, A. (2014) Analyzing Computer Programming Job Trend Using Web Data Mining. Issues in Informing Science and Information Technology, 19-21 November 2012, Madrid, Spain. IATED. pp. 203-214. Sørum, H. \& Pettersen, L. (2016) In Need of an Interaction Designer? What the Industry Wants and What it Actually Gets! In: Eikerbrokk, T, Karlsen, A., Kaasbøll, J., Netteland, G., Opdahl, A., Rolland, K. and Sindre, G. (eds.) NOKOBIT 2016: Norsk Konferanse om Organisasjoners Bruk av IT, 28-30 November 2016, Bergen, Norway. Bibsys Open Journal Systems.

Wade, M.R. \& Parent, M. (2002) Relationship Between Job Skills and Performance: A Study of Webmasters. Journal of Management Information Systems. 18 (3), 71-96.

Yang, M.Y., You, M. \& Chen, F.C. (2005) Competencies and Qualification for Industrial Design Jobs: Implications for Design Practice, Education, and Student Career Guidance. Design Studies. 26 (2), 155-189. Available from: doi: 10.1016/j.destud.2004.09.003 


\section{Appendix}

\section{Description of the codes in our coding Scheme}

\begin{tabular}{|c|c|c|}
\hline \multirow{3}{*}{ 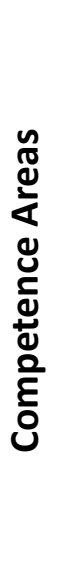 } & $\begin{array}{l}\text { Responsive Design } \\
\text { (CA.1) }\end{array}$ & $\begin{array}{l}\text { Implement responsive web experiences and interactive prototypes; } \\
\text { ability to create interactive assets for websites, digital media, social ads } \\
\text { that accommodate all screen sizes; experience in building highly polished } \\
\text { responsive user interface using HTML and CSS; knowledge in responsive } \\
\text { web design; implement responsible web design principles to ensure that } \\
\text { clients project renders well across multiple devices. }\end{array}$ \\
\hline & $\begin{array}{l}\text { Project Management } \\
\text { (CA.2) }\end{array}$ & $\begin{array}{l}\text { Manage all social media platforms and websites; setting up and managing } \\
\text { websites with leading CMS application (WordPress, Drupal, Joomla): } \\
\text { managing multiple creative projects simultaneously. }\end{array}$ \\
\hline & $\begin{array}{l}\text { Handling Deadline } \\
\text { (CA.3) }\end{array}$ & $\begin{array}{l}\text { Able to work to tight deadlines; work well under pressure and meet } \\
\text { deadline; deadline-oriented; provide accurate timing estimates on work; } \\
\text { must able to manage workload and meet critical project milestones and } \\
\text { deadlines. }\end{array}$ \\
\hline
\end{tabular}

\begin{tabular}{|c|c|c|}
\hline \multirow{8}{*}{ 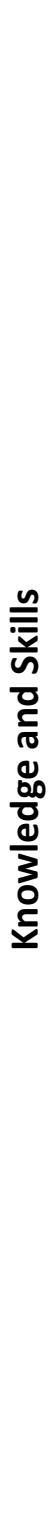 } & $\begin{array}{l}\text { Conceptual } \\
\text { Design Skills }\end{array}$ & \\
\hline & $\begin{array}{l}\text { Creativity } \\
\text { (KS.1) }\end{array}$ & $\begin{array}{l}\text { Ability to be creative in design; ability to translate other's concept into visual } \\
\text { captivating graphics; thinking creatively to produce new ideas, concepts, } \\
\text { and developing interactive design; ability to collaborate, ideate, and deliver } \\
\text { UX concepts for new websites, apps, and customer touch points; transform } \\
\text { wireframes and verbal concepts into working prototypes. }\end{array}$ \\
\hline & $\begin{array}{l}\text { Problem Solving Skills } \\
\text { (KS.2) }\end{array}$ & $\begin{array}{l}\text { Demonstrate problem solving skills; creative thinker and problem solver; } \\
\text { must be conversant with solving other IT problems; understand user pain } \\
\text { points in existing designs and provide user-friendly solutions to these } \\
\text { roadblocks. }\end{array}$ \\
\hline & $\begin{array}{l}\text { Design } \\
\text { Research } \\
\text { (KS.3) }\end{array}$ & $\begin{array}{l}\text { Investigate new resources to use which will improve functionality, usability, } \\
\text { loading speed, and search engine (SEO); researching current design trends; } \\
\text { must have a firm understanding of changing technologies, including } \\
\text { software and tools for web design. }\end{array}$ \\
\hline & $\begin{array}{c}\text { Technical } \\
\text { Design Skills }\end{array}$ & \\
\hline & $\begin{array}{l}\text { User-Interface Prototyping } \\
\text { (KS.4) }\end{array}$ & $\begin{array}{l}\text { Experience in any rapid prototyping tool - Axure RP, InVision, Balsamiq, } \\
\text { Sketch; design a framework for creating user apps that grow with the } \\
\text { needs of the client; capable of converting Photoshop/Fireworks mock-ups } \\
\text { into CSS/XHTML; and "execute all visual design stages from low fidelity } \\
\text { wireframes, interactive prototypes, to final high fidelity mock-ups required } \\
\text { by technical team and stakeholders. }\end{array}$ \\
\hline & $\begin{array}{c}\text { Coding/Programming } \\
\text { Skills (KS.5) }\end{array}$ & $\begin{array}{l}\text { Top-notch programming skills and in-depth knowledge of modern HTML/ } \\
\text { CSS; working knowledge of HTML, CSS, JavaScript, and bootstrap or } \\
\text { equivalent framework; solid understanding of HTML5, CSS3, JQuery, PHP, } \\
\text { and responsive design; must have a fair knowledge in HTML, CSS, and } \\
\text { JavaScript. }\end{array}$ \\
\hline & $\begin{array}{l}\text { Web Hosting Support } \\
\text { (KS.6) }\end{array}$ & $\begin{array}{l}\text { Upload the site onto a server and register it with different search engines; } \\
\text { testing website to ensure it is working and identify any technical problem; } \\
\text { setting and managing websites with leading CMS application (WordPress, } \\
\text { Drupal, Joomla). }\end{array}$ \\
\hline
\end{tabular}




\begin{tabular}{|c|c|c|}
\hline & Software Tools & \\
\hline & $\begin{array}{l}\text { Prototyping Tool } \\
\text { (KS.7) }\end{array}$ & $\begin{array}{l}\text { Experience in any rapid prototyping tool-Axure RP, InVision, Balsamiq, } \\
\text { Sketch; proficiency in Photoshop for prototyping; experience in using } \\
\text { prototyping software to build user interface from wireframes; and must } \\
\text { know how to slice from Photoshop into a website. }\end{array}$ \\
\hline & $\begin{array}{l}\text { Developing Tools } \\
\text { (KS.8) }\end{array}$ & $\begin{array}{l}\text { In-depth knowledge on industry leading software (Adobe Dreamweaver); } \\
\text { proficient in Dreamweaver and related web developing software. }\end{array}$ \\
\hline & $\begin{array}{l}\text { Deploying Tool } \\
\text { (KS.9) }\end{array}$ & $\begin{array}{l}\text { Knowledge on hosting cPanel; ability to use FileZilla to upload and download } \\
\text { web content onto live server; asuccessful candidate should be able to put } \\
\text { apps in Google Play. }\end{array}$ \\
\hline & $\begin{array}{l}\text { Content Management } \\
\text { System (CMS) } \\
\text { (KS.10) }\end{array}$ & $\begin{array}{l}\text { Setting up and managing websites with leading CMS applications } \\
\text { (WordPress, Drupal, Joomla). }\end{array}$ \\
\hline \multirow{5}{*}{$\begin{array}{l}\frac{n}{\pi} \\
\frac{\pi}{0} \\
\frac{\pi}{0} \\
\frac{\pi}{0} \\
\frac{\mathscr{0}}{0} \\
0\end{array}$} & $\begin{array}{l}\text { Willingness to Learn } \\
\text { (PT.1) }\end{array}$ & $\begin{array}{l}\text { continual professional development to keep up to date with software } \\
\text { developments; willing and ready to learn and implement what is learnt; } \\
\text { must be motivated to continue learning. }\end{array}$ \\
\hline & $\begin{array}{l}\text { Independency } \\
\text { (PT.2) }\end{array}$ & ability to work independently under pressure without supervision. \\
\hline & $\begin{array}{l}\text { Teamwork } \\
\text { (PT.3) }\end{array}$ & $\begin{array}{l}\text { Must be a team player; work collaboratively with our marketing and content } \\
\text { team to capture design requirements and translate them into innovative } \\
\text { digital solutions; working as part of a multidisciplinary team. }\end{array}$ \\
\hline & $\begin{array}{l}\text { Acumen } \\
\text { (PT.4) }\end{array}$ & Demonstrated ability to take leadership role in new and current projects. \\
\hline & $\begin{array}{l}\text { Passion } \\
\text { (PT.5) }\end{array}$ & $\begin{array}{l}\text { passion for creating experiences in online environments; passion for } \\
\text { technology and learning; demonstrate a good aesthetic sense and passion } \\
\text { for design. }\end{array}$ \\
\hline
\end{tabular}

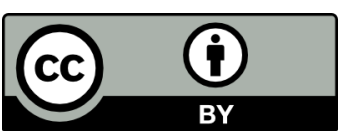

(C) 2020 Authors. Published by the University of Novi Sad, Faculty of Technical Sciences, Department of Graphic Engineering and Design. This article is an open access article distributed under the terms and conditions of the Creative Commons Attribution license 3.0 Serbia (http://creativecommons.org/licenses/by/3.0/rs/). 